\title{
The discovery of the school of gladiators at Carnuntum, Austria
}

\author{
Wolfgang Neubauer ${ }^{1,2}$, Christian Gugl ${ }^{3}$, Markus Scholz ${ }^{4}$, Geert \\ Verhoeven $^{1,2}$, Immo Trinks ${ }^{1}$, Klaus Löcker ${ }^{1,5}$, Michael Doneus ${ }^{1,2}$, \\ Timothy Saey ${ }^{6} \&$ Marc Van Meirvenne ${ }^{6}$
}

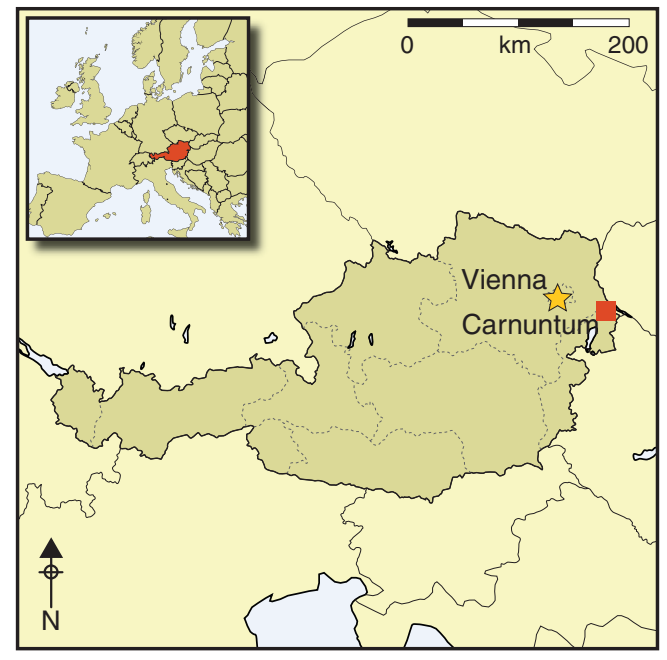

Sophisticated techniques of archaeological survey, including airborne imaging spectroscopy, electromagnetic induction and ground-penetrating radar, are opening up new horizons in the non-invasive exploration of archaeological sites. One location where they have yielded spectacular results is Carnuntum in Austria, on the south bank of the Danube, capital of the key Roman province of Pannonia. Excavations in the late nineteenth and twentieth centuries revealed many of the major elements of this extensive complex, including the legionary fortress and the civilian town or municipium. Excavation, however, is no longer the only way of recovering and recording the details of these buried structures. In 2011, a combination of non-invasive survey methods in the area to the south of the civilian town, where little was visible on the surface, led to the dramatic discovery of remains interpreted as a gladiatorial school, complete with individual cells for the gladiators and a circular training arena. The combination of techniques has led to the recording and visualisation of the buried remains in astonishing detail, and the impact of the discovery is made all the greater by the stunning reconstruction images that the project has generated.

Keywords: Austria, Carnuntum, Roman Empire, gladiators, ludus, remote sensing, geophysics

1 Ludwig Boltzmann Institute for Archaeological Prospection and Virtual Archaeology, Hohe Warte 38, A-1190 Vienna, Austria

2 VIAS (Vienna Institute for Archaeological Science), University of Vienna, Franz-Klein-Gasse 1, A-1190 Vienna, Austria

3 Austrian Academy of Sciences, Institute for the Studies of Ancient Culture, Bäckerstraße 13, A-1010 Vienna, Austria

4 Römisch-Germanisches Zentralmuseum, Forschungsinstitut für Vor-und Frühgeschichte, Ernst-Ludwig-Platz 2, D-55116 Mainz, Germany

5 Archeo Prospections ${ }^{\circledR}$, Central Institute for Meteorology and Geodynamics, Hohe Warte 38, A-1190 Vienna, Austria

6 Research Group Soil Spatial Inventory Techniques, Department of Soil Management, Faculty of Bioscience Engineering, Ghent University, Coupure 653, B-9000 Ghent, Belgium

(C) Antiquity Publications Ltd.

ANTIQUITY 88 (2014): 173-190

http://antiquity.ac.uk/ant/088/ant0880173.htm 
Supplementary material is available at http://antiquity.ac.uk/projgall/neubauer339/

\section{Introduction}

In September 2011 the discovery of a gladiatorial school (ludus gladiatorius or simply ludus) at Carnuntum was announced to the public by the Ludwig Boltzmann Institute for Archaeological Prospection and Virtual Archaeology (LBI ArchPro) and its international partner consortium (Neubauer \& Seren 2012: 4). This unique discovery was enabled by systematically applying a multi-disciplinary approach based on remote sensing and highresolution near-surface geophysical prospection (Neubauer 2011; Neubauer et al. 2012). The foundations of a large buried building complex, including a circular training arena, cell blocks, training and assembly halls, infrastructure, practice fields, a bath complex and an administrative wing were mapped in three dimensions in unprecedented detail. The completeness of preservation of this gladiatorial school at Carnuntum is considered unique in the entire former Roman Empire. This paper presents the first detailed description of the non-invasive techniques applied and provides a first archaeological interpretation of the newly discovered monuments.

\section{The archaeological landscape of Carnuntum}

Approximately $40 \mathrm{~km}$ south-east of Vienna on the southern bank of the River Danube, the site of Roman Carnuntum (Figure 1) constitutes the largest archaeological landscape in Austria and has been investigated by archaeologists for more than a century (Doneus et al. 2001). Roman Carnuntum was located on slightly undulating fluviatile gravel terraces that were covered at the end of the Weichselian glacial period by aeolian loess deposits with a variable but generally limited thickness (Saey et al. 2013). The Danube flows from west to east, cutting through the foothills of the Carpathian mountain ridge at the eastern limits of the site, and the local landscape characteristics are largely determined by the river. At present, the main soil type of the area is classified as a calcic chernozem (Neubauer et al. 2002). The central archaeological zone of Carnuntum covers an area of approximately $650 \mathrm{ha}$ between the modern villages of Petronell-Carnuntum and Bad Deutsch Altenburg.

As the capital of the Roman province of Pannonia, the Colonia Septimia Aurelia Antoniniana Karnuntum was an important town on the limes during the first four centuries $\mathrm{AD}$. The buried remains consist, to the east, of a legionary fortress with associated auxiliary camps, and surrounded by an extensive civilian settlement, the canabae legionis (Doneus et al. 2013). The western part was dominated by the civilian town with an adjacent vicus, the autonomous municipium Aelium Karnuntum (hereafter Carnuntum) founded by the emperor Hadrian around AD 124. Systematic aerial photography revealed that numerous villae and vici were distributed across the hinterland to the south of Carnuntum. Only a few monuments dating to the Roman period survive as upstanding remains above ground, the most prominent being the 'Heathen's Gate', a quadrifrons originally $15 \mathrm{~m}$ high, and an amphitheatre south of the civilian town. The ruins of the latter had been unearthed by excavations in the 1920s. At that time the site had been identified as a municipal amphitheatre (Figure 2).

So far, only small parts of this extended archaeological site and its surrounding landscape have been investigated through archaeological excavations. These were mainly conducted (C) Antiquity Publications Ltd. 
Wolfgang Neubauer et al.

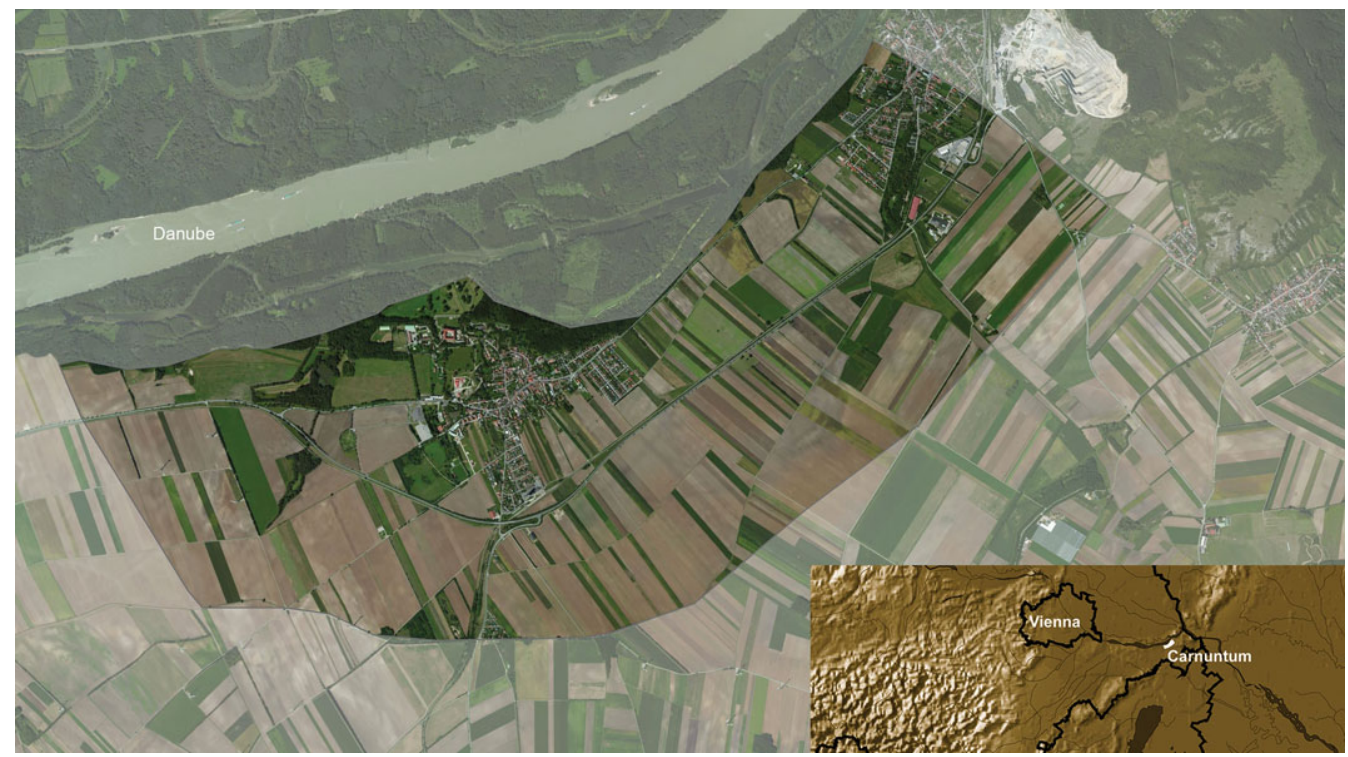

Figure 1. Location of the Roman town of Carnuntum in Lower Austria (graphics: Klaus Löcker and Michael Doneus).

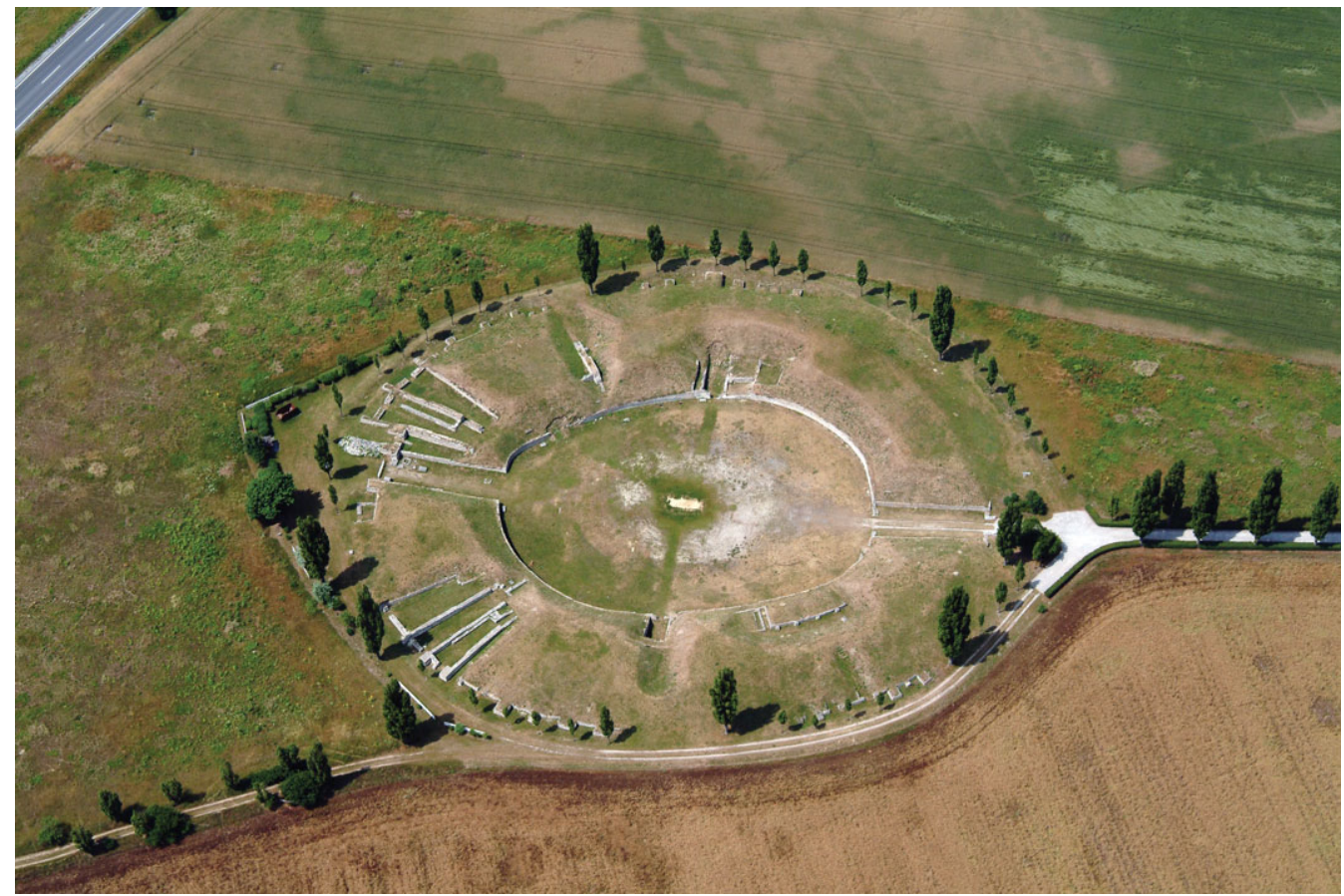

Figure 2. Aerial photograph of the municipal amphitheatre at Carnuntum. Vegetation marks in the field in the background partly outline the gladiatorial school (photo: Michael Doneus).

(C) Antiquity Publications Ltd. 
between the years 1877 and 1913. While Carnuntum was called 'Pompeii at the gates of Vienna' in the nineteenth century due to the exceptionally good state of preservation of its ruins, this situation has changed drastically in recent decades. Intensive farming involving deep ploughing for vineyards, coupled with infrastructure development, the construction of new housing estates in the nearby villages, and active looting by treasure hunters has caused a dramatic increase in the irreversible destruction of the archaeological deposits and cultural heritage.

For more than 15 years, this archaeological landscape has been the focus of a large-scale project of archaeological prospection (Neubauer et al. 2012). This was initiated by ZAMG Archeo Prospections ${ }^{\circledR}$ and the University of Vienna (Doneus et al. 2001; Eder-Hinterleitner et al. 2003; Doneus \& Neubauer 2005) and continued in 2010 by LBI ArchPro. The main objective of this project is the non-invasive mapping of the Roman landscape (Figure 1) by applying and developing the latest remote sensing and geophysical near-surface prospection methods and technologies for the imaging of buried Roman structures at unprecedented resolution and scale.

\section{The municipal amphitheatre}

The western amphitheatre (Figure 2) south of the civilian town was erected outside the municipium (Figure 3) in the first half of the second century AD, and was modified many times during later phases, as shown by excavations conducted from 1923 to 1930 (Egger 1926; Miltner 1933). Measuring $126.5 \mathrm{~m}$ by $111 \mathrm{~m}$, the civilian amphitheatre was larger than the corresponding military amphitheatre located next to the legionary fortress to the east. The main entrances of the municipal amphitheatre were located on the northern and southern sides of the building. They were divided by rows of columns or pillars into three passageways. A sanctuary of Nemesis (Fortuna Karnuntina) was integrated into the southern entrance area, identified by several inscriptions dedicated to this well-known goddess of the amphitheatre (Egger 1926: 124-28, fig. 44; Hornum 1993: 41, 164-66, nos. 18-20). Visitors could reach the seats by staircases and even stair towers, one of which has been preserved. From the evidence found, spectator seating has been reconstructed as having been up to $25 \mathrm{~m}$ in height; from this it is estimated that the civilian amphitheatre could host approximately 13000 spectators. Two small chambers, which have been interpreted as animal cages, were located along the walls on either side of the arena. Despite the early excavations, the surroundings of the amphitheatre remained mostly terra incognita. In 1941, during the Second World War, a small-scale excavation was carried out in a building west of the amphitheatre without any results (Kandler 2004: 46). First indications of significant structures located near the amphitheatre came from aerial photographs showing a main Roman road leading from the town towards it, with buildings and memorials along its eastern side, whereas to the west of the road no structures at all were visible.

\section{Integrated archaeological prospection}

Repeated aerial reconnaissance flights over Carnuntum in the 1990s showed vague soil and vegetation marks in a field immediately to the west of the amphitheatre, indicating for the (C) Antiquity Publications Ltd. 


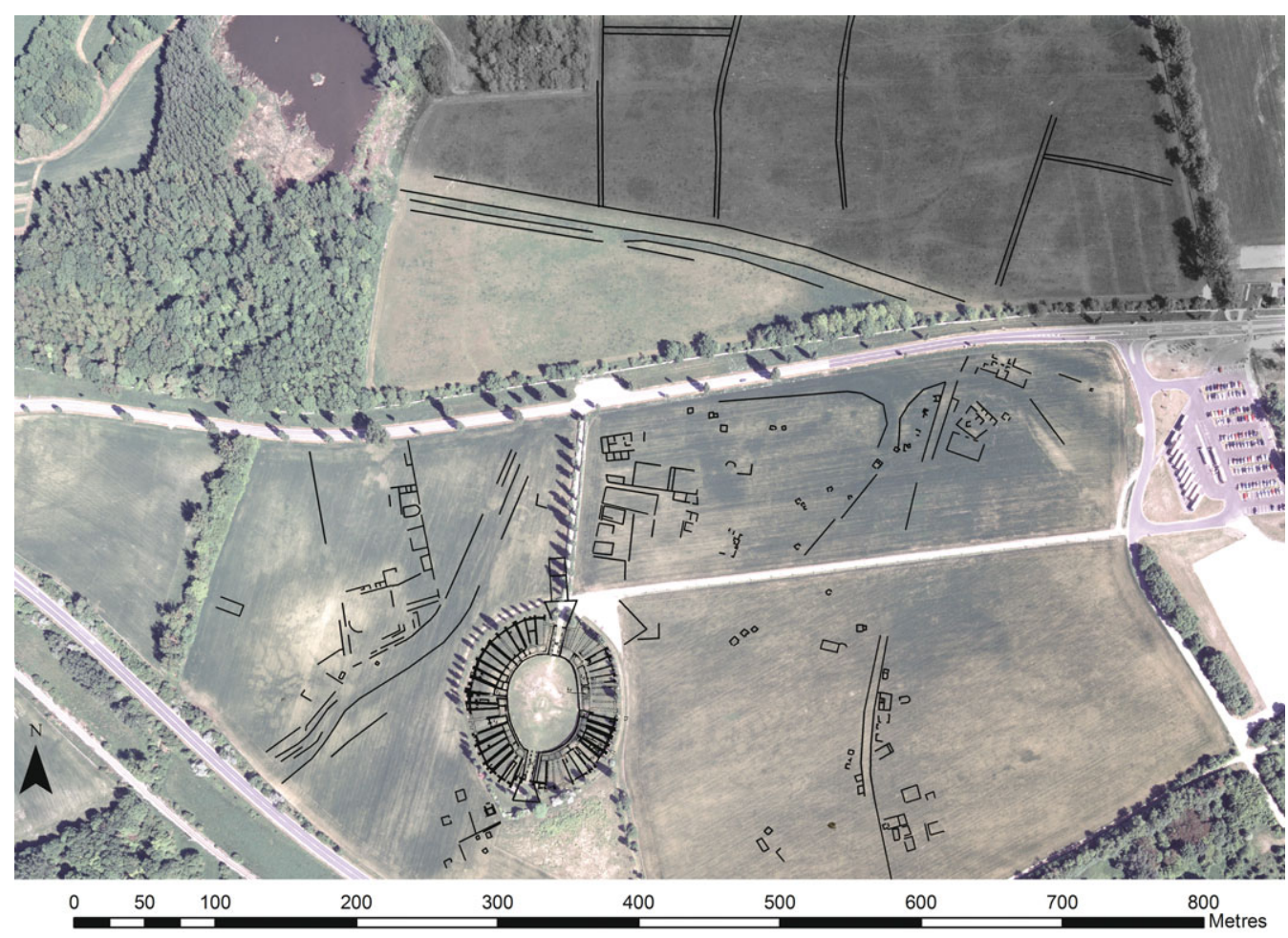

Figure 3. Archaeological interpretation of an orthophoto from late summer 2011 of the south-western part of the civilian town of Carnuntum combined with the excavation map of the municipal amphitheatre. To the west of the amphitheatre the remains of the gladiatorial school are visible. To the north the street system and the main fortification of the municipium show up as faint vegetation marks in the grassland (graphics: Wolfgang Neubauer).

first time the buried remains of buildings. In 2000, the first magnetic survey was carried out to investigate the anomalies observed from the air, using a manually operated five-sensor PICODAS MEP750 Caesium magnetometer system with Picotesla sensitivity (Figure 4B). The magnetometer data, sampled with a spatial resolution of $12.5 \mathrm{~cm} \times 50.0 \mathrm{~cm}$, revealed traces of the foundation walls of a large trapezoidal building complex, as well as associated infrastructure, such as a main aqueduct belonging to the water supply system of the Roman town. In the same year, a ground-penetrating radar (GPR) survey was conducted using a Sensors \& Software pulseEkko 1000 system with $900 \mathrm{MHz}$ antennae towed manually in a sledge with $5 \mathrm{~cm}$ in-line and $50 \mathrm{~cm}$ cross-line GPR trace spacing.

Magnetometer surveys result in 2D images (Figure 5) representing subtle anomalies in the intensity of the Earth's magnetic field, without direct information about the depth of the buried structures. In contrast, GPR surveys provide detailed 3D information about the approximate depth, shape and location of archaeological structures. The collected GPR data generated equidistant GPR depth-slices (Figure 6), which are 2D data images at certain depth levels displaying considerably more details of the large building complex. Animations of the depth-slices revealed concentric circular structures in the building's courtyard, providing first indications on the function of the large complex. 


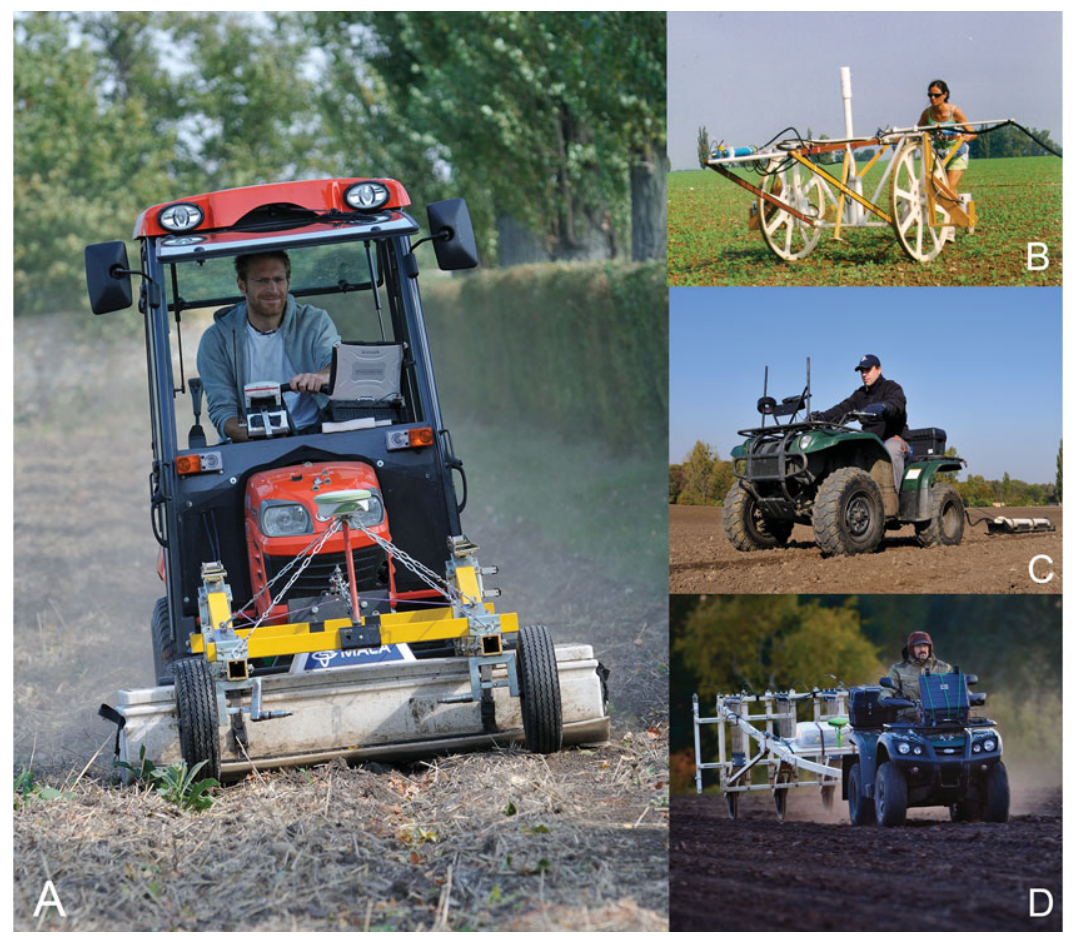

Figure 4. Geophysical measurement systems used in the detection of the gladiatorial school at Carnuntum: A) the MAL $\AA$ Imaging Radar Array (MIRA) with $16 \times 400 \mathrm{MHz}$ channels spaced at $8 \mathrm{~cm}$. The RTK-GPS receiver is situated centrally above the GPR antenna box. The system is hydraulically mounted in front of a small tractor; B) PICODAS MEP750 Caesium magnetometer with five sensors (sensitivity 0.001nT) manually operated with optoelectronic distance measurement; C) motorised dual EM-21S sensor with four coils; D) motorised 10-sensor Foerster fluxgate gradiometer array operated behind a quad ATV (photos: Geert Verhoeven and Wolfgang Neubauer).

Recent technological and methodological advances leading to greatly increased efficiency of archaeological prospection formed the background for a renewed integrated investigation of the area by a multinational team of archaeologists, geophysicists, soil scientists and IT experts from LBI ArchPro and its international partners. In spring 2011, the team started with a high-definition GPR survey of the structural remains, using a MAL $\AA$ Imaging Radar Array (MIRA) system in motorised configuration (Figure 4A). This MIRA system consists of $16 \times 400 \mathrm{MHz}$ channels with $8 \mathrm{~cm}$ cross-line channel spacing and possibilities for $4 \mathrm{~cm}$ or $8 \mathrm{~cm}$ in-line GPR trace spacing tracked by a real-time kinematic GPS with centimetre accuracy, permitting operating speeds of $12-15 \mathrm{~km} / \mathrm{h}$ (Trinks et al. 2010).

The recorded GPR data were processed into depth-slice images (Figure 6) using special imaging software developed by LBI ArchPro in close collaboration with ZAMG Archeo Prospections ${ }^{\circledR}$. Subsequently, the new GPR results have been complemented by magnetometer data acquired using a novel GPS-tracked motorised 10-sensor Foerster fluxgate gradiometer array (Figure 4D), extending the coverage (Figure 5) of the initial Caesium magnetometer survey area. In collaboration with the research group ORBit from Ghent University, high-resolution electromagnetic induction (EMI) data were acquired in autumn 2011 by successfully employing a novel four-coil DualEM-21S sensor towed by

(C) Antiquity Publications Ltd. 


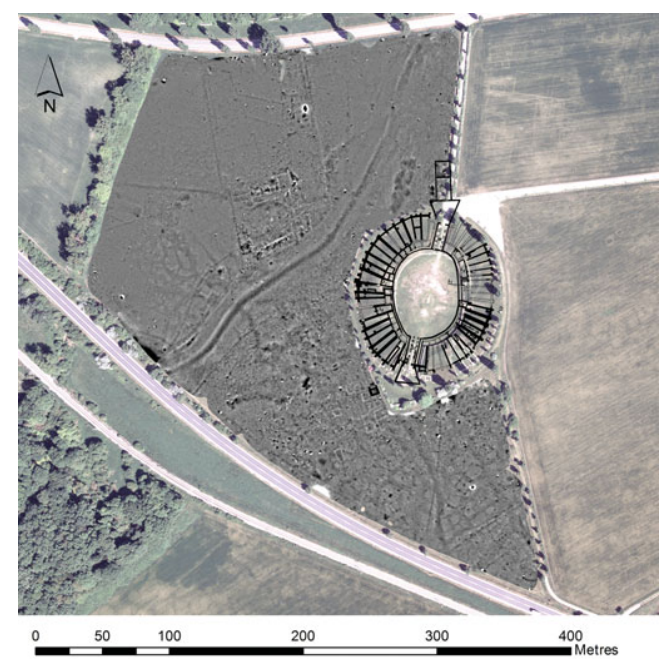

Figure 5. Magnetogram of the western area around the municipal amphitheatre showing the remains of the gladiatorial school and its surroundings. The prominent winding linear feature indicates a ditch dug for the installation of an aqueduct. As the building complex clearly respects this ditch, it is assumed to predate the construction of the gladiatorial school. An extended refuse dump obvious in the magnetic and radar data at the southern corner of the building proves that the ditch in Roman times was a distinct depression separating the gladiatorial school from the surrounding area of the amphitheatre (graphics: Wolfgang Neubauer and Alois Hinterleitner). a quad bike and using differential GPS for data positioning and navigation (Figure 4C). The EMI data (Saey et al. 2013) provided information complementary to the GPR and magnetic data, because of its simultaneous measurement of the magnetic susceptibility and apparent electrical conductivity of overlapping soil volumes (Figure 7).

In the meantime, LBI ArchPro partner Airborne Technologies conducted an airborne imaging spectroscopy (AIS) survey of Carnuntum. In contrast to the three spectral bands acquired by the earlier conventional aerial photography, AIS typically captures more than 100 small bands of electromagnetic radiant energy per pixel location. The resulting threedimensional data cube stacks images for every spectral band acquired, forming a spectrally extended version of aerial photography. The dense sampling of the spectral domain allows very subtle soil and vegetation properties to be mapped (Verhoeven \& Doneus 2011). On 5 June 2011 an AIS flight conducted with the Specimaisa EAGLET system covered the entire city of Carnuntum. Data were acquired in 105 spectral bands ranging from $400 \mathrm{~nm}$ to $1000 \mathrm{~nm}$ with a ground-sampling distance of $40 \mathrm{~cm}$. During the same AIS flight, high-resolution topographical data were obtained using a Riegl LMS-Q680 airborne laser scanner. Post-processing to georeference and radiometrically calibrate the flight strips was followed by the application of recently developed processing algorithms to extract all archaeologically relevant information (Atzberger $e t$ al. forthcoming; Doneus et al. forthcoming). The processed AIS imagery (Figure 8A) is clearly superior to conventional RGB aerial images (Figure $8 \mathrm{~B}$ ) and enables enhanced archaeological interpretation. The remote sensing and near-surface geophysical investigations were followed up by a field survey using a raster of $10 \mathrm{~m} \times 10 \mathrm{~m}$ in October 2012. The plough soil assemblages were systematically collected over an area of $2.45 \mathrm{ha}$. Preliminary assessment of the collected pottery reveals that the artefacts generally date to the second and third centuries AD. This coincides well with the chronology known from the municipal amphitheatre.

The integration of individual survey methods in combination with a detailed digital terrain model and georeferenced excavation map situates the newly discovered Roman remains and their topographic position in context with the amphitheatre, associated infrastructure and environmental setting. Furthermore, this integrated data set places the whole site within a rough temporal frame. Combining all of the data permitted an integrated

(C) Antiquity Publications Ltd. 

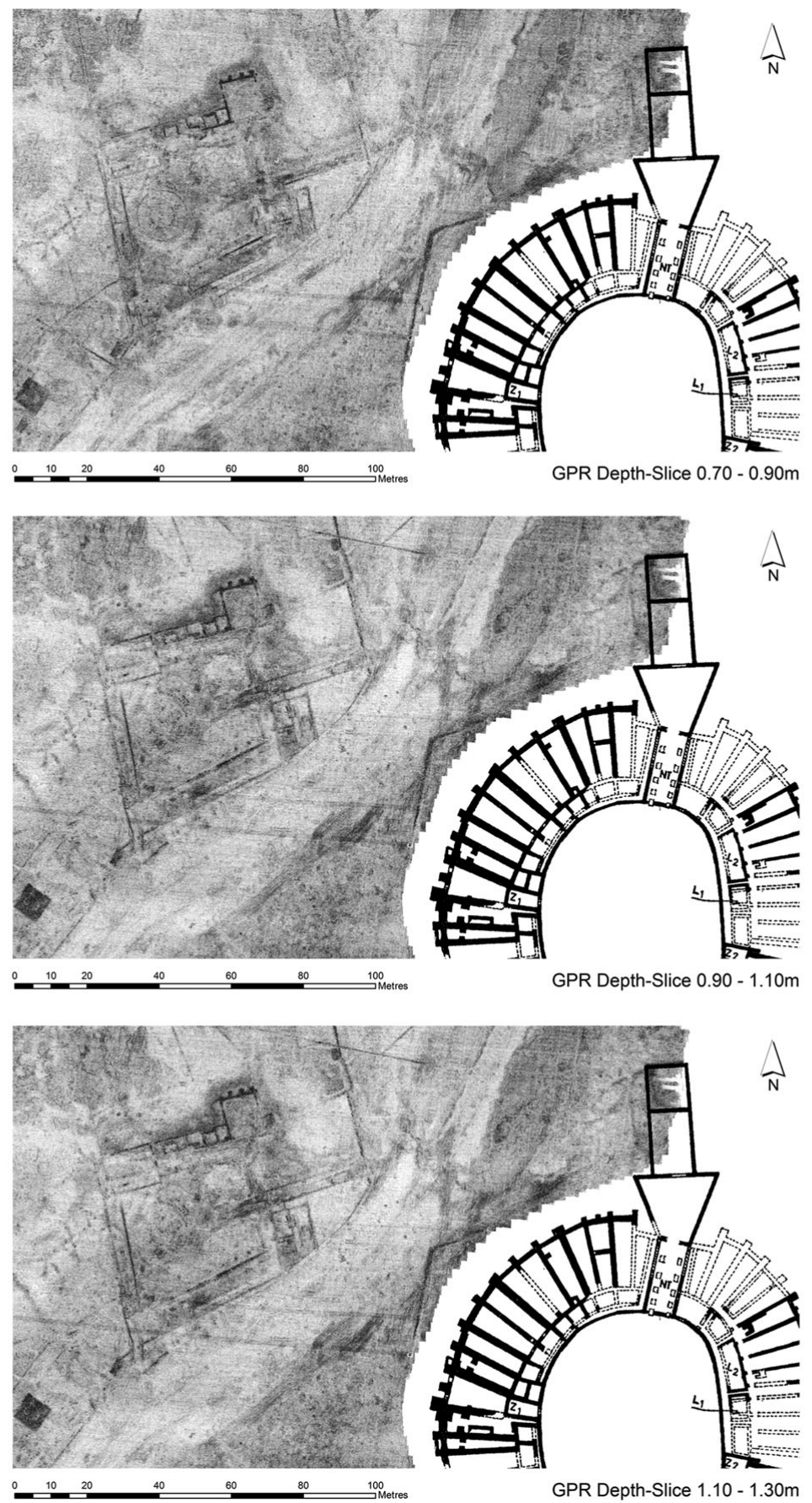

Figure 6. Radargrams visualised as horizontal depth-slices from 0.7 to $1.3 \mathrm{~m}$ deep produced from the MIRA 16-channel ground-penetrating radar data measured in a resolution of $8 \mathrm{~cm} \times 4 \mathrm{~cm}$. Within the courtyard a circular structure can be seen (19m in diameter) interpreted as the training arena of the gladiators (graphics: Wolfgang Neubauer and Alois Hinterleitner).

(C) Antiquity Publications Ltd. 


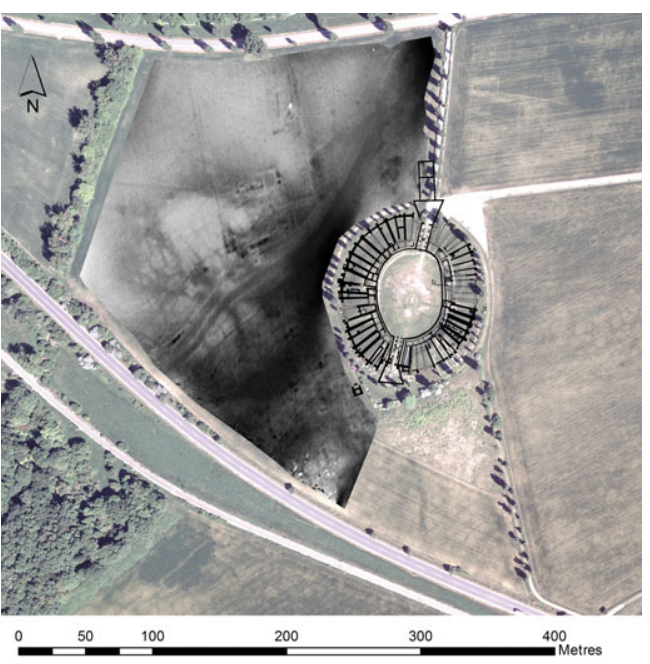

Figure 7. Composite image of the apparent electrical conductivity and magnetic susceptibility measured with the DualEM-21S multi-receiver EMI sensor showing the remains of the gladiatorial school and its surroundings. Graphics: Timothy Saey and Marc Van Meirvenne.
GIS-based analysis of the archaeological stratification near the amphitheatre in relation to the underlying geology, the hydrological setting and the geomorphology, notably palaeorelief and pedology. The detailed geophysical and archaeological interpretation of the integrated prospection data, as realised within the GIS, resulted in $2 \mathrm{D}$ interpretation maps and a $3 \mathrm{D}$ subsurface interpretation model (Figure 9) of the detected remains of the ludus. The outstandingly well-preserved architecture was presented through virtual excavation within an integrated 3D data volume produced by high-resolution, nondestructive prospection methods (Ch'ng et al. 2011), followed by the generation of a virtual reconstruction model (Figures 1011 and online supplementary material).

\section{The school of gladiators-archaeological interpretation}

The main building complex of the newly detected monument at Carnuntum covers $2800 \mathrm{~m}^{2}$ located within a walled plot of about $11000 \mathrm{~m}^{2}$ west of the municipal amphitheatre and outside the Roman civilian town (Figure 12). The rectangular area is oriented north-south with no adjacent buildings or enclosures detectable outside the enclosed area. At the southern end of the walled area, the main buildings are arranged around a central inner courtyard $1100 \mathrm{~m}^{2}$ in extent, resulting in a building area of $1700 \mathrm{~m}^{2}$ (Figure 9). The main architectural
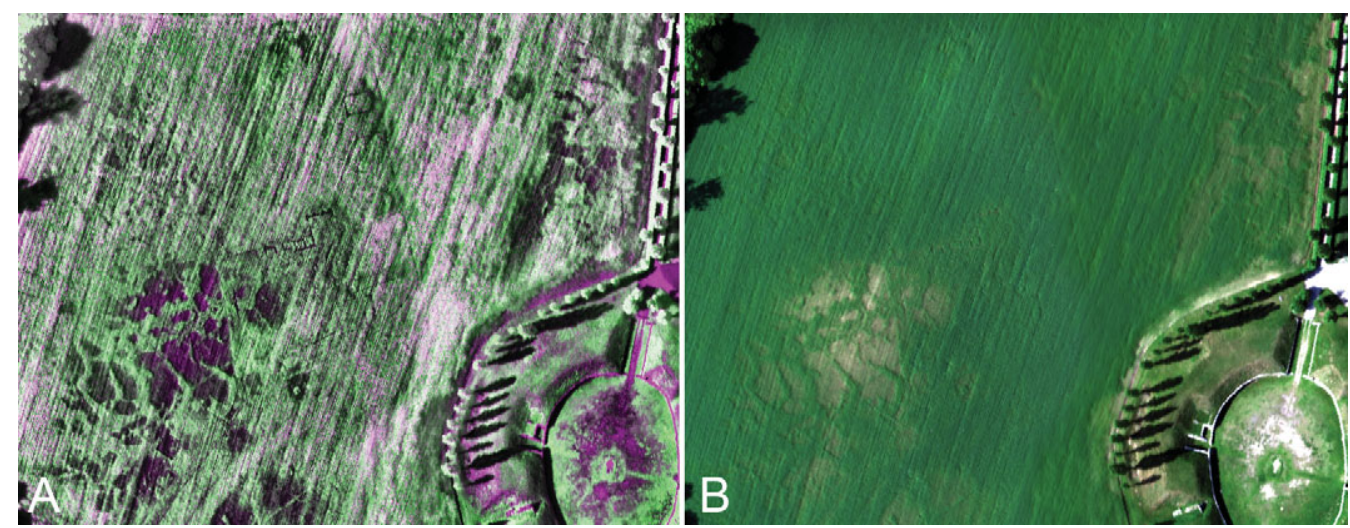

Figure 8. Comparison of histogram-stretched images derived from airborne imaging spectroscopy and conventional aerial photography: A) a false colour composite image created from the airborne imaging spectroscopy data clearly outlining the layout of the building complex; B) the same area in a conventional RGB aerial image (images: Geert Verhoeven).

(C) Antiquity Publications Ltd. 


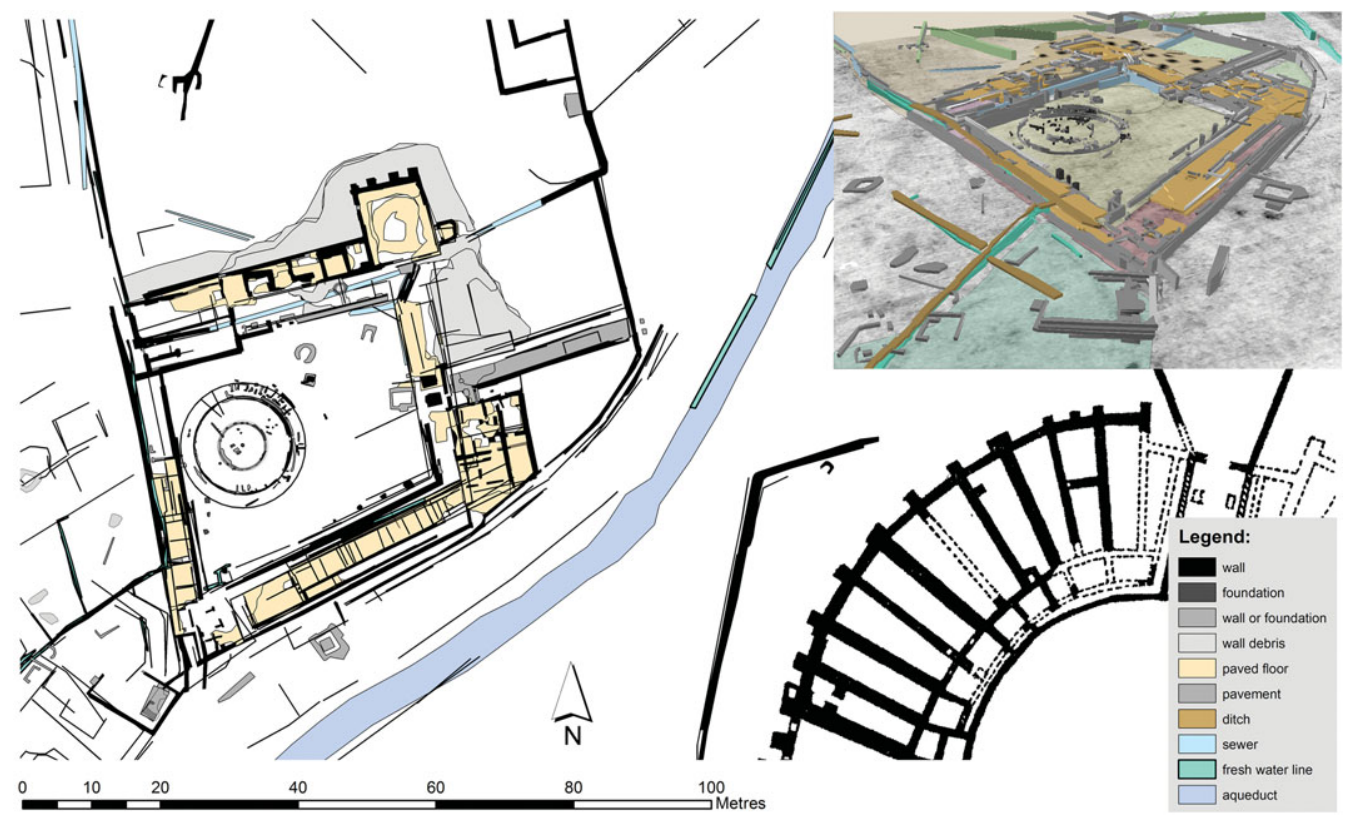

Figure 9. GIS-based archaeological interpretation map of the gladiatorial school at Carnuntum derived from the groundpenetrating radar and magnetic data. Inset upper right: Three-dimensional visualisation of the GIS-based archaeological interpretation model derived from the ground-penetrating radar depth-slices (graphics: Wolfgang Neubauer).

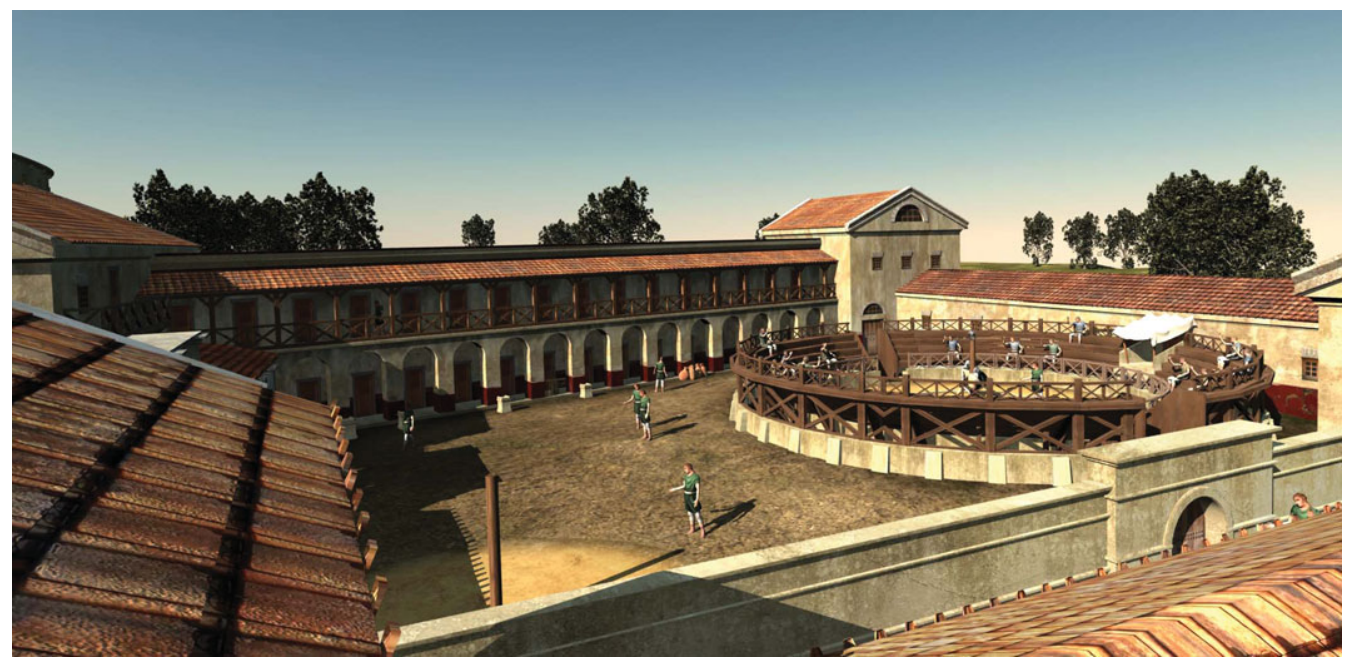

Figure 10. Virtual reconstruction model of the school of gladiators at Carnuntum. View from the north into the courtyard with the training arena (graphics: Michael Klein).

complex had been erected at the highest local elevation, which is formed by a gravel outcrop marking a buried hill left by the meandering Weichselian Danube, as detected by integrating the electrical conductivity (EC) measurements. As this gravel outcrop largely coincides with the location of the building complex, we assume that the Romans selected (C) Antiquity Publications Ltd. 


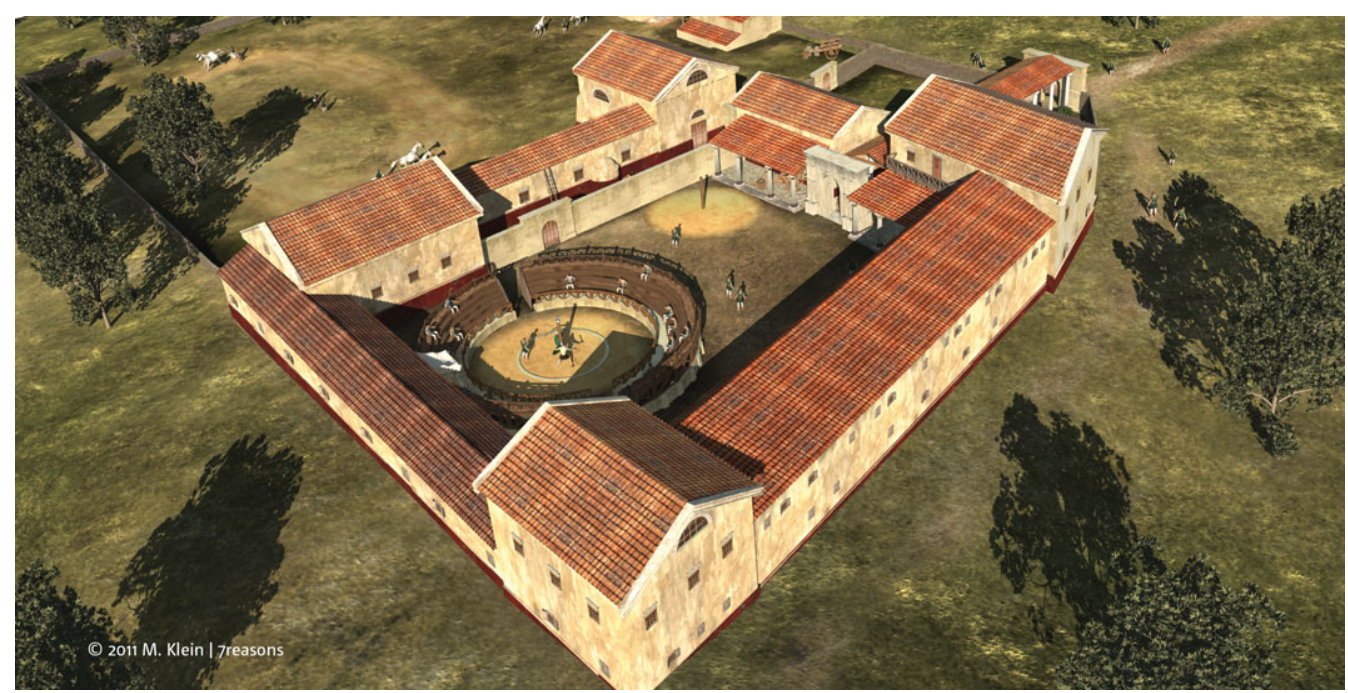

Figure 11. Virtual reconstruction model of the school of gladiators at Carnuntum. View from the south (graphics: Michael Klein).

this specific location because it provided a stable and erosion-free foundation. Most of the wall foundations had been dug into the gravel subsoil, except along the northern edge, where a clay overburden was identified by the EC measurements.

The interpretation of this complex as a school of gladiators, a so-called ludus, is based on a series of different arguments. First, there is the close topographical relationship to the civilian amphitheatre. Then there is the internal structure that presents specific arrangements which confirm the proposed interpretation.

A single and easily controlled entrance into the complex can be seen on its eastern side, facing the amphitheatre. The walking distance from the gateway to the northern main gate of the amphitheatre is approximately $80 \mathrm{~m}$. Access to the walled complex was clearly restricted and may only have been possible through this $2.4 \mathrm{~m}$-wide gate. A paved access path $28 \mathrm{~m}$ long and $2.2 \mathrm{~m}$ wide and enclosed by walls on both sides incorporates a driveway and a separate path. The walls are interpreted as the base of a portico or canopy. The access path ends at the front gate of the building, leading into the courtyard. No anomalies were discernible to either side, indicating that there were no other permanent structures outside the building complex. The geophysical data indicate that these were garden areas. That to the north is clearly larger and ends at a massive wall separating the buildings from the large enclosed area beyond. The access path ends at a formal entranceway defined by the narrow sides of two rectangular buildings. These two buildings can clearly be discerned in the prospection data to the right and left of the front gate and formed the frontage of the entire building complex. The southern building is in a better state of preservation than the northern building. We interpret this part of the complex as the administrative block and living quarters of the school's owner, the lanista (Bomgardner 2000: 33; Meijer 2007). The lanista was head of his familia gladiatoria with complete legal power over the life and death of the gladiators - unless they were Roman citizens. 


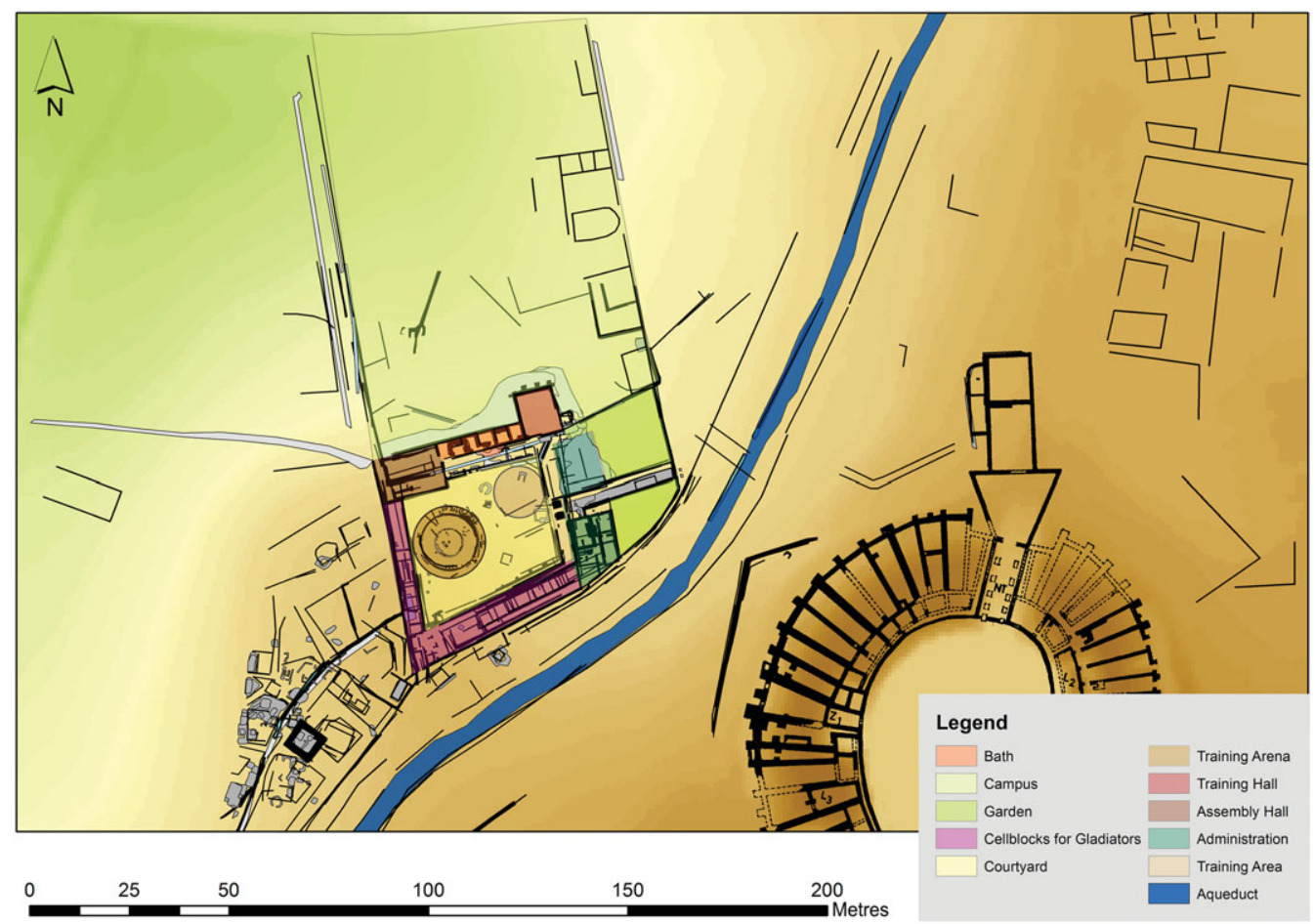

Figure 12. GIS-based archaeological interpretation map of the gladiatorial school at Carnuntum derived from the groundpenetrating radar and magnetic data combined with the topographic model derived from airborne laser scanning (graphics: Wolfgang Neubauer).

Passing through the front gate gave direct admission to the courtyard, via a structure like a triumphal arch clearly discernible as two $4.4 \mathrm{~m} \times 3.8 \mathrm{~m}$-wide foundations. The most prominent feature inside the courtyard is a free-standing circular structure $19 \mathrm{~m}$ in diameter, which could be interpreted as the training arena for the gladiators. This arena was surrounded by wooden spectator stands set on stone foundations that are clearly discernible in the GPR data. Evidence for a feature resembling a post-hole was recorded by the GPR measurements in the centre of the arena. This might be the foundation of the palus, a wooden pole used for exercising blows with the sword and body slams with the shield (Futrell 2006). The training arena and the foundation of the palus are the strongest arguments-beside the context and the various findings to be described below-for interpreting the complex as a gladiatorial school. The importance of this pole can also be deduced from the hierarchical system within the familia gladiatoria, which was based on a standard ranking system within each armament type, as many gladiatorial epitaphs and commemorative reliefs from across the Empire attest (Carter 2003: 89-93). The ranking was based on the abilities of the gladiators to use a specific type of weaponry in front of the palus: primus palus, secundus palus, etc. (Carter 2003: 93-95; Futrell 2006; Meijer 2007). The division of the gladiators by the use of pali facilitated training and instruction specific to the type of armament. The instructors or trainers (doctores or magistri) specialised, just as the gladiators did, in

(C) Antiquity Publications Ltd. 
a particular armament type. Exceptional gladiators were those who could fight with more than one type of equipment.

The ground of the training arena consisted of gravel covered with sand, featuring a $6.7 \mathrm{~m}$ diameter inner ring delimited by a wall. The function of the inner ring is not immediately clear, but it may have served as the foundation for a portable barrier during training shows involving wild beasts. The spectator stand has a width of $2.4 \mathrm{~m}$. Allowing $0.6 \mathrm{~m}$ for each row of seats, up to four levels can be assumed. The larger foundations in the north-east of the training arena indicate a staircase to access the tiers. The arena had a convergent entrance in the north-west, providing access for the gladiators from a $45 \mathrm{~m}^{2}$ hall in the north-western corner of the courtyard. This hall had only a front door with a doorsill $0.4 \mathrm{~m}$ wide and $1.9 \mathrm{~m}$ long, indicating a massive door frame. No traces of a pavement are visible, and the hall most likely was furnished with wooden flooring. It could be interpreted as the room where the gladiators were equipped with their armament for training or special shows for investors.

The arena abuts the western wing of the building complex, where foundations indicate a special raised area for prominent spectators or high-ranking investors who were selecting gladiators for forthcoming spectacles. The purpose of this training area may have been to provide a private place for a limited audience to inspect new gladiators and their fighting techniques and specific skills. In the north-eastern corner of the courtyard, another circular anomaly discernible in the GPR data suggests an additional training area without spectator stands. The circular layout of the training arena is not one commonly documented in Roman amphitheatre architecture. In addition to the customary elliptical shape of amphitheatres, however, there are a few examples of circular buildings that were probably used for gladiatorial games, both in Italy and in the provinces (Golvin 1988: pl. 20, no. 3; Sommer 2009).

Accommodation for the gladiators was most likely located in the southern and perhaps partly in the western wing of the building complex. As indicated by the foundations, the southern wing had a portico facing the courtyard. The southern wing shows a central row of small cells $3-7 \mathrm{~m}^{2}$ in area arranged within an elongated cell block (total size $130 \mathrm{~m}^{2}$ ), which could be accessed from the north and south as indicated by the respective corridors. This same design is also found at the barracks at the ludus magnus, the gladiatorial school close to the Flavian amphitheatre in Rome. The western wing shows larger paved rooms at the back of the raised viewing area with foundations indicating a staircase and additional cells or rooms in the southern third of this wing. The consistently strong magnetic signal from some of the cell-sized rooms indicates floors covered with small tiles. These rooms were the most elaborate within the western wing of the building, and were most likely reserved for the highest ranking gladiators or the instructors, many of whom probably were drawn from the ranks of senior and ex-gladiators (Carter 2003: 95).

The cell blocks in the western and southern wings are connected by a $90 \mathrm{~m}^{2}$ corner building with evidence of additional stairways. It was most probably used for instructors or supervisors, other staff and related infrastructure. The corner building was accessible from the courtyard through a door right in the corner of the barracks. The southern barracks of the school and the lanista's buildings were at least two storeys high, as indicated by the typical stairway corridors. Assuming a single gladiator inhabiting each of the smallest cells of $3 \mathrm{~m}^{2}$, and taking into account the two-storey character of the southern gladiator barrack block, an estimated total of 75 gladiators could have been housed within this wing of the ludus.

(C) Antiquity Publications Ltd. 
At a distance of $1.2 \mathrm{~m}$ from the courtyard-facing front of the barracks, a row of rectangular foundations spaced $4 \mathrm{~m}$ apart was detected. These may be the foundation blocks for memorials. Below the main entrance path in front of the triumphal arch, a $2.8 \mathrm{~m} \times 1.5 \mathrm{~m}$ sunken cell accessible by a ramp or stairs with a height of less than $0.8 \mathrm{~m}$ was located by the GPR measurements. This sunken cell, constructed without access to daylight and so low that standing was impossible, was probably used for disciplinary measures.

The northern wing of the building complex was accessible from the courtyard through a $1.3 \mathrm{~m}$-wide gate leading into a closed compound $\left(570 \mathrm{~m}^{2}\right)$ of the school. A massive wall seals off the courtyard from the corridor that gives access to the northern part of the building. This corridor, $3.9 \mathrm{~m}$ wide and $30 \mathrm{~m}$ long, was most likely not roofed but had the function of a pathway connecting the three individual parts of the northern wing, which were accessible solely from this corridor.

The most prominent architectural element is a protruding rectangular building or hall with interior dimensions of $8.7 \mathrm{~m} \times 10.5 \mathrm{~m}$ at the north-eastern corner of the complex. Animations of the GPR depth-slices indicate an internal structure of varying shape and irregular distance from the wall, which is caused by a sloping surface interpreted as a collapsed pavement. Collapse to that degree is only imaginable by assuming a corresponding hollow space underneath the pavement. From our experience, this clearly indicates the presence of a hypocaust system for under-floor heating. The large furnace, the $6.5 \mathrm{~m}^{2}$ praefurnium, can be found on the eastern wall of the hall close to its south-eastern corner. On its northern side, the hall shows four protruding bench foundations supporting the main wall in the area where the EC measurements provided evidence for a clay overburden on the gravel. The necessity for these additional foundations on the softer ground also relates to the exceptional height of the hall. This conclusion is supported by the massive layers of debris found surrounding the hall, caused by the structural collapse of the walls. The entrance is discernible in the middle of the southern wall, connecting the heated hall with the open corridor. As temperatures in winter normally fall to $-25^{\circ} \mathrm{C}$ in combination with strong easterly winds, we interpret this building either as a heated training room or an assembly hall.

A second distinct part of the northern wing is formed by six paved rooms $\left(100 \mathrm{~m}^{2}\right.$ in area) arranged in a row. The eastern four rooms $\left(78 \mathrm{~m}^{2}\right.$ in area) seem to be internally connected, forming a functional unit accessible from outside through a door in the middle of the corridor. The second room to the east shows an apse on its southern side, whereas the following room has a bank basement indicating a pool in the north and shows supporting pillars for a heated floor. The apse and this basement are connected with the sewer system, discussed below. On the eastern side of the apse a circular depression for a fountain or well has been detected, providing a direct supply of fresh water for this wing. The massive pavement visible in the GPR data and the typical magnetic anomaly characterising these four rooms indicates they formed another heated part of the building. The apse and the basement seem to have supported water basins. We interpret this part of the building as a bath complex which could have been used by both the gladiators and, during the time when all gladiators where locked in their cells, by the lanista's family.

Both of the two adjacent rooms to the west are directly accessible through doors from the corridor, indicating a function distinct from the bath. Another $200 \mathrm{~m}^{2}$ building was detected (C) Antiquity Publications Ltd. 
at the western end of the northern wing. Access to this area was possible through a door $1.4 \mathrm{~m}$ wide at the western end of the corridor. The building shows internal walls forming two larger compartments partly paved at the north-eastern edge. Two adjacent rooms to the west are accessible from the north-western corner of the building complex and from outside the walled compound to the north. Accessible without entering the ludus proper, and therefore less isolated, these rooms were probably used as a storage facility.

The gladiators represented a substantial investment for their lanista, and they were well cared-for. A high-energy diet, daily massage and high quality medical care were provided alongside the severe discipline and training regime. The discovery and detailed mapping of the ludus at Carnuntum proves for the first time that gladiators could recover from the harsh and difficult training in a fully equipped Roman bath. Training carried on throughout the entire year. So far, only the rooms and facilities for medical treatment, a refectory, a kitchen and a latrine are missing from this reconstruction of daily gladiatorial life (Junkelmann 2008). The western part of the northern wing provides the necessary space and infrastructure, as well as the logical configuration, to suggest that these facilities were located within this part of the ludus.

The magnetic survey revealed an important aqueduct passing along the south-eastern front of the ludus, erected in an artificial channel adapted to cut across the original terrain. A primary water line branched off the aqueduct and conducted the water along a local ridge to ingress through the south-western front of the ludus. The water conduits supplying all four wings around the courtyard can be traced inside the building. The sewer system is clearly identifiable in the GPR results, with two drain lines along the western wall of the campus and another passing below the corridor of the northern wing. The second and wider sewer crosses the north-western corner building running directly beneath a rather wide wall, hinting at the position of the latrines. This conduit had a large waste and rainwater inlet draining the courtyard at the north-eastern corner. To the east of the main door into the southern barracks it is possible to discern another isolated foundation, which is connected by a linear anomaly to the fresh water line entering the western wing. It is most likely the footing for a fountain.

To the north-west and within a further walled compound an extended open campus adjoins the school.

In the immediate vicinity of the ludus, spatially segregated from other burial grounds at Carnuntum, we discovered what is probably the cemetery of the gladiators, immediately behind the building complex, with large burial monuments, stone sarcophagi and other, simpler graves. This area is still under investigation and more details will be presented in a future paper on the ludus at Carnuntum. That will include studies on parts of a gladiatorial helmet and other (non-military) weapons, discovered in 1901 in Aequinoctium-Fischamend, some $18 \mathrm{~km}$ west of Carnuntum, which were found in an area used as a graveyard (Groller 1903: 40-48, figs. 18-19).

\section{Conclusions}

Given its state of preservation, dimensions and architecture, the newly discovered ludus at Carnuntum is considered to be unique. Although it is estimated that over 100 ludi must 
have been built throughout the Roman period (Meijer 2007), most of them have been destroyed or covered over. The only known building directly comparable to the find made in Carnuntum is the partially excavated ludus magnus behind the Coliseum (Amphitheatrum Flavium) in Rome (Colini \& Cozza 1962). Unlike the new discovery, the ludus magnus is only partly accessible today and fewer details have been preserved. The housing of gladiators in Pompeii can hardly be compared with the Carnuntum ludus. The so-called caserma dei gladiatori at Pompeii seems to be the location for a small private familia gladiatoria, far away from the amphitheatre, whereas the gladiatorial training area in the so-called Quadriporticus is interpreted as an evacuation quarter after the Pompeii earthquake of AD 62 (Golvin 1988: 149-54; Jacobelli 2003: 65-68, figs. 54-55).

The unique archaeological discovery of a ludus exemplifies the tremendous amount of highly detailed information that can be gathered by employing the latest multidisciplinary, entirely non-invasive and hence archaeologically sustainable prospection approach, as promoted by LBI ArchPro. Both aerial photography and geophysical data show that the archaeological heritage has suffered severe damage. This case study exemplifies a longterm approach to the survey of Roman archaeological landscapes which was introduced at the Archaeological Prospection Conference in 2001 (Doneus et al. 2001; Doneus $\&$ Neubauer 2005). The discovery and public presentation of the ludus has convinced stakeholders of the benefits of this methodology to archaeological heritage, and new funds have been raised. As a result, the central area of the archaeological landscape of Carnuntum (Figure 1, highlighted) will be mapped over the course of the next three years in a large-scale prospection project directed by LBI ArchPro. Through combining aerial archaeology and modern remote sensing with ground-based high-resolution geophysical subsurface mapping and subsequent GIS-based archaeological interpretation and spatial analysis, the basis for sustainable cultural heritage management is established. The resulting archaeological maps and plans of individual buildings, streets and Roman infrastructure allow the virtual reconstruction of the city layout and the development of ancient land- and townscapes in two and three dimensions. These provide scholars, planning authorities and the public alike with detailed information about the ancient city of Carnuntum (Doneus et al. 2013). This non-invasive and sustainable approach to the archaeological survey of Roman city sites provides a model for modern, time- and cost-efficient archaeological research, covering not only the individual archaeological site but also its surrounding landscape, an approach in full compliance with the Valetta Convention (Council of Europe 1992).

\section{Acknowledgements}

The authors wish to express their thanks to the team at LBI ArchPro and its partners. The data acquisition was carried out by S. Seren, E. Bayirli, U. Fornwagner, Ch. Zingerle, N. Trochsler, A. Hinterleitner, E. Nau, T. Zitz, M. Kucera, G. Verhoeven, M. Doneus, T. Saey, V. Van Parys, W. Neubauer, Ch. Gugl and Airborne Technologies GmbH. Data processing was completed by A. Hinterleitner, M. Pregesbauer, G. Verhoeven and T. Saey. The GIS-based interpretation model was developed by W. Neubauer. The archaeological interpretation was accomplished by W. Neubauer, M. Scholz, F. Humer and Ch. Gugl. The initial virtual reconstruction was developed by W. Neubauer and M. Klein. The Ludwig Boltzmann Institute for Archaeological Prospection and Virtual Archaeology (http://archpro.lbg.ac.at) is based on an international cooperation of the Ludwig Boltzmann Gesellschaft, the University of Vienna, the Vienna University of Technology, ZAMG-the Austrian Central Institute for Meteorology and Geodynamics, the Province of Lower Austria, Airborne Technologies,

(C) Antiquity Publications Ltd. 
RGZM-the Roman-Germanic Central Museum Mainz, RAÄ-Swedish National Heritage Board, IBM VISTAUniversity of Birmingham and NIKU-Norwegian Institute for Cultural Heritage Research.

\section{References}

Atzberger, C., M. Wess, G. Verhoeven \& M. DONEUS. Forthcoming. A Matlab GUI for imaging spectroscopy in archaeology. International Journal of Remote Sensing (submitted).

BOMgardner, D.L. 2000. The story of the Roman amphitheatre. London: Routledge.

CARTER, M. 2003. Gladiatorial ranking and the "SC de Pretiis gladiatorum Minuendis" (CIL II $6278=$ ILS 5163). Phoenix 57.1-2: 83-114.

Ch'NG, E., H. Chapman, V. Gaffney, P. Murgatroyd, C. GafFney \& W. Neubauer. 2011. From sites to landscapes: how computing technology is shaping archaeological practice. Computer 44(7): 40-46.

Colini, A.M. \& L. CozzA. 1962. Ludus Magnus. Roma: Monte dei paschi di Siena.

Council of Europe. 1992. Valletta Convention. ETS no. 143-European Convention on the Protection of the Archaeological Heritage (revised). Available at: http://conventions.coe.int/Treaty/en/Treaties/Html/ 143.htm (accessed 21 July 2013).

Doneus, M. \& W. Neubauer. 2005. Multiple survey techniques at Roman Carnuntum. Integrated prospection of the largest archaeological landscape in Austria, in Ch. Musson, R. Palmer \& S. Campana (ed.) In volo nel passato. Aerofotografia e cartografia archeologica: 272-79. Siena: Biblioteca del Dipartimento di Archeologia e Storia delle Arti.

Doneus, M., A. Eder-Hinterleitner \& W. NeUbaUer. 2001. Roman Carnuntumprospecting the largest archaeological landscape in Austria, in M. Doneus, A. Eder-Hinterleitner \& W. Neubauer (ed.) Archaeological Prospection, 4th International Conference on Archaeological Prospection: 47-59. Vienna: Austrian Academy of Sciences Press.

Doneus, M., Ch. Gugl \& N. Doneus. 2013. Die Canabae von Carnuntum: eine Modellstudie der Erforschung römischer Lagervorstädte. Von der Luftbildprospektion zur siedlungsarchäologischen Synthese (Der römische Limes in Osterreich 47). Wien: Austrian Academy of Sciences Press.

Doneus, M., G. Verhoeven, C. Atzberger \& M. Rus. Forthcoming. Turning hyperspectral pixels into archaeological information. Archaeological Prospection.
Eder-Hinterleitner, A., P. Melichar, W. Neubauer, M. Doneus \& S. Seren. 2003. The city map of ancient Carnuntum—combining archaeological prospection, photogrammetry and GIS. Archaeologia Polona 41: 156-57.

EgGER, R. 1926. Das zweite Amphitheater, in Der römische Limes in Österreich 16: 69-158. Wien: Hölder-Pichler-Tempsky.

FUTRELL, A. 2006. The Roman games: a sourcebook. Oxford: Blackwell.

GOLVIN, J.-C. 1988. L'amphithéâtre romain: essai sur la théorisation de sa forme et de ses fonctions (Publications du Centre Pierre Paris 18). Paris: De Boccard.

Groller, M. 1903. Straßen- und Limesforschung, in M. Groller, R. Münsterberg \& E. Bormann (ed.) Der römische Limes in Österreich 4: 1-52. Wien: Alfred Hölder.

Hornum, M.B. 1993. Nemesis, the Roman state, and the games (Religions in the Graeco-Roman World 117). Leiden: Brill.

JACOBELli, L. 2003. Gladiatori a Pompei: protagonisti, luoghi, immagini. Roma: "L'Erma" di Bretschneider.

Junkelmann, M. 2008. Gladiatoren-Das Spiel mit dem Tod. Mainz: Philipp Von Zabern.

KAndleR, M. 2004. Carnuntum, in M. Šašel Kos \& P. Scherrer (ed.) The autonomous towns of Noricum and Pannonia/Die autonomen Städte in Noricum und Pannonien: Pannonia II: 11-66. Ljubljana: Narodni Muzej Slovenije.

MeIJER, F. 2007. The gladiators: history's most deadly sport. New York: St. Martin's Griffin.

Miltner, F. 1933. Das zweite Amphitheater von Carnuntum (Der römische Limes in Osterreich 17). Wien: Austrian Academy of Sciences Press.

Neubauer, W. 2011. Archäologische Prospektion der Landschaft Carnuntum, in E. Bilek-Czerny \& M. Doneus (ed.) Carnuntum und Limes (Denkmalpflege in Niederösterreich 45): 23-26. St. Pölten: Amt der NO Landesregierung, Abteilung Kultur und Wissenschaft.

Neubauer, W. \& S. Seren. 2012. Die Entdeckung der Gladiatorenschule in Carnuntum. Acta Carnuntina 2(1): 4-13.

Neubauer, W., A. Eder-Hinterleitner, S. Seren \& P. MELICHAR. 2002. Georadar in the Roman civil town Carnuntum, Austria: an approach on archaeological interpretation of GPR data. Archaeological Prospection 9: 135-56. 
Neubauer W., M. Doneus, I. Trinks, G.

Verhoeven, A. Eder-Hinterleitner, S. Seren \&

K. LÖCKER. 2012. Long-term integrated archaeological prospection at the Roman town of Carnuntum, Austria, in P. Johnson \& M. Millett (ed.) Archaeological survey and the city (University of Cambridge Museum of Classical Archaeology Monographs 2): 202-21. Oxford: Oxbow.

Saey, T., M. Van Meirvenne, P. De Smedt, W. Neubauer, I. Trinks, G. Verhoeven \& S. Seren. 2013. Integrating multi-receiver EMI measurements to interpret the soil-landscape around the school of gladiators, Carnuntum, Austria. European Journal of Soil Science 64: 716-27.
SOMmER, C.S. 2009. Amphitheatres of auxiliary forts on the frontiers, in T. Wilmott (ed.) Roman amphitheatres and spectacula: a $21^{\text {st }}$-century perspective: papers from an international conference held at Chester, 16 ${ }^{\text {th }}-18^{\text {th }}$ February, 2007 (British Archaeological Reports international series 1946): 47-62. Oxford: Archaeopress.

Trinks, I., B. Johansson, J. Gustafsson, J. Emilsson, J. Friborg, C. Gustafsson, J. Nissen \& A. Hinterleitner. 2010. Efficient, large-scale archaeological prospection using a true three-dimensional ground-penetrating radar array system. Archaeological Prospection 17: 175-86.

Verhoeven, G. \& M. Doneus. 2011. Balancing on the borderline-a low-cost approach to visualize the red-edge shift for the benefit of aerial archaeology. Archaeological Prospection 18: 267-78.

Received: 22 January 2013; Accepted: 25 April 2013; Revised: 10 June 2013

(C) Antiquity Publications Ltd. 